\title{
The Impact of Cooperative Education: Considering Employability and Career Advancement of New Graduates
}

\author{
Wannapa Luekitinan
}

\begin{abstract}
This study aimed to compare the employability and the career advancement of cooperative students and non-cooperative students, including to identify the correlation among cooperative education program attendance and initial job, started income and period to get the job. The population was 1,807 new graduates who graduated in academics year 2015 from the faculty and the college that has the cooperative education in the curriculum at Burapha University, Thailand. The questionnaire was employed to gather the data and the questionnaires were sent to the population by e-mail. For data analysis, the Independence Sample t-Test and Chi-square test were used to analyze the data. The findings revealed the employability and career advancement of cooperative students and non-cooperative students were not different. Except, the employability in term of problem-solving skill and leadership had the difference between cooperative students and non-cooperative students. Regarding the correlation analysis, the cooperative education program attendance statistical significant related to the initial job, started income and period to get the job at 0.05 . The cooperative students have been worked in the field or related filed more than the non-cooperative students. Moreover, the cooperative students received the started income more than 15,000 Bath and had the period to get the new job below 3 months.
\end{abstract}

Index Terms-Cooperative education, career advancement, employability, new graduated.

\section{INTRODUCTION}

Cooperative education is a teaching method that focuses on learning from experience and the actual work in the workplace. There are various names based on this concept, including experiential education, work-study program, work-based education, sandwich program, and internship. However, the most common name that widely uses in the world are cooperative education and work integrated learning. The main content of cooperative education composes of two concepts. Firstly, recognize the importance of career preparation and the entry into work system before graduated of the students. Secondly, the development of graduate quality according to the needs of the labor market by providing students with direct experience in the real-life workplace that based on learning by doing principle.

The cooperative education takes the advantage of all stakeholder that are students, employers, and educational institutions. For the student benefit, the students who join the cooperative education program will have a systematic thinking, study motivation, problem-solving skill, ability to

Manuscript received November 28, 2017; revised May 15, 2018.

Wannapa Luekitinan is with the Human Resource Management Program, Faculty of Management and Tourism, Burapha University, Thailand (e-mail: wannapa.w236@yahoo.com). apply the theory, communication skill, human relation skill, and self-confidence [1]. In addition, joining the cooperative education program helps students to identify career goals and have the confidence in professional knowledge. This is the chance that the students can contract the employer before gradated [2].

For Thailand, Prof. Dr. Wichit Srisa-an is the first person who introduces the cooperative education in 2003 at Suranaree University of Technology. This concept was extended to public and private universities. In 2004, Deputy Minister of Education announced the policy to support financial fund to the university which applied the cooperative education in the learning process. The subsidies were allocated directly to 17 universities that provided instruction through cooperative education. Nowadays, the government has continued to promote cooperative education and work integrated learning and support all resources through the Office of Higher Education.

However, most universities have still faced the staff and resource problem. Especially the staff problem, someone does not understand the cooperative education concept and wonder about the student benefit [2]. The study aimed to compare employability and career advancement of the new graduates who attended cooperative education program and who do not, including to identify the correlation among cooperative education program attendance and initial job, started income and period to get the job.

This paper consists of six parts that are the introduction, literature review, methodology, findings, discussion, and conclusion and suggestion.

\section{LITERATURE REVIEW}

\section{A. Cooperative Education}

Cooperative education is one of the most widely accepted learning patterns for over 100 years. The first founder of this concept was Herman Schneider, who introduced the concept to engineering students at the University of Cincinnati in 1906. Whereupon, the concept was applied to other universities in engineering studies, such as Northeastern University in 1909, Drexel University and the Massachusetts Institute of Technology in 1919. For the field of social sciences, this concept was applied in 1921.

Cooperative Education is a part of work integrated learning (WIL) that highlight on university student full-time employment. This employment is a kind of learning activity in the curriculum and the opportunity for students to integrate their knowledge in the classroom with the work experience [1]. Moreover, Wilson and Lyons [3] identified the cooperative education is a model of integrated learning in the 
classroom and experience in the industry, business and government. The students who participate in the cooperative education program have to work in the organization at least 16 weeks. The project assignment and work performance would be set to assess the student graduation.

Heinemann, Wilson, Heller, and Craft [4] said that cooperative education is a practical experience that is an important part of the educational process and can be held at the high school, college or even university. This program requires work assignments that are relevant to the area studied by students or meet the interest of the students. The duration of cooperative education should consider the sufficient for learning the full experience. Therefore, the cooperative education must set the criteria for evaluation. When the cooperative education program has ended, the academic staff should hold the student presentation and sharing section. This could show the progress of students. However, the definition of cooperative education varies from time to time. It depends on economic conditions and the area of study [5], as well as the degree of cooperative education may vary from educational institution due to different education curriculum structure.

The cooperative education beneficial to all stakeholders who participate in the program; students, employer, and educational institution. Considering student benefit, students participating in the cooperative education program would have more systematic thinking skill, communication skill, interrelation skill, problem-solving skill, and the ability to apply the theory. Furthermore, the cumulative GPA, study motivation, self-confidence may higher [1]. Participation in the cooperative education program also allows students to identify career goals and have confidence in professional knowledge. This is an opportunity to contact with employers and to get the job interview experience, including the development of knowledge that meets the needs of the organization [2].

In addition to employer benefit, employers can select and employ the qualified personnel and reduce the cost of recruiting employees [1], [2], [6]. This program is also creating corporate image and social responsibility [6], including improving the coaching skills of the staff who serve as mentors [2]. In the interest of cooperative education of educational institutions, the program would help develop curriculum in accordance with the needs of the labor market. It is also a channel for research funding and resources; such as scientific instrument supply and laboratory development [2]. In addition, cooperative education also increased the graduated employment rate [1].

\section{B. Employability}

Employability skills not only are basic skills necessary for doing well on a job but also are considered as the contribution to employers. Generally, the employability consists of basic academic skills, thinking skills, and personal qualities [7]. However, employability skill may change over time and categorize in many different ways due to the evolution of knowledge, technology, and globalization [8]. From previous research identified many skills that that labor market and employers required as shown in Table I. For these employability, the student should have before graduated.
TABLE I: EMPLOYABILITY

\begin{tabular}{ll}
\hline \hline \multicolumn{1}{c}{ Employability } & \multicolumn{1}{c}{ Reference } \\
\hline Management and & {$[9]-[15]$} \\
Commercial Skill & {$[10],[12]-[16]$} \\
Communication Skill & {$[9][11][12][13][16]$} \\
Leadership & {$[9][10][11][12][15][16][17]$} \\
Interrelationship Skill & {$[9][10][11][12][13][14][17]$} \\
Data Management and & \\
Information Technology & \\
Skill & {$[10][11][12][14][15][18]$} \\
Teamwork & {$[10][11][12][13][14][15][16]$} \\
Problem Solving Skill & \\
\hline \hline
\end{tabular}

\section{Career Advancement}

For the past, career path means the vertically upward in the organization from one specific to the next job level or higher level. Following the established career path, there is other career path that emerges and suit for the rapidly business changing; such network career paths and dual career paths [19]. Moreover, the flatter organization structures required new skill sets that influenced career development potential. The modern flatter structure was found to have negatively impacted career advancement opportunities [20].

From employees' perspective, career path may involve weaving from company to company and from position to position as the employees obtain knowledge and experience. By selecting an alternative career path, a person may transfer current skill into the new career [19]. Kaplan [21] noted the workers look for impressive job titles, higher compensation, and more responsibility, as well as, Robst [22] identified employees' willingness to embrace continuously learning certainly should faster career advancement.

\section{Methodology}

The population were 1,807 graduates who graduated in academics year 2015 from the faculty and the college that has the cooperative education at curriculum in Burapha University, Thailand; that were faculty of Management and Tourism, Faculty of Logistics, Faculty of Informatics, International College, Faculty of Fine Arts, Faculty of Science and Social Science, Faculty of Science and Humanity, and Faculty of Agriculture Technology.

The questionnaire was employed to gather the data and the questionnaires were sent to the population by e-mail. The self-assessment questionnaire was designed on the basis of a thorough literature review that consisted of participant characteristics section, and another was employability and career advancement that were five-point Likert scale ranging from 1 to 5 (strongly disagree to strongly agree).

The employability consist of seven items that are management and commercial skill, communication skill, leadership, interrelationship skill, data management and information technology skill, teamwork, and problem solving skill. For the career advancement, the five items were summed up to give a summated scores that consisted of 1) New challenge work assignment, 2) The promotion in training and development, 3) Trust, 4) Job empowerment, and 5) Chance to introduce new ideas.

For data analysis, the Independence Sample t-Test and Chi-square test were used to analyze the data. The result 
showed the 1,457 completed questionnaires were returned and the response rate is $80.63 \%$ as shown in Table II.

TABLE II: THE SAMPLE CHARACTERISTICS

\begin{tabular}{lcc}
\hline \multicolumn{1}{c}{ The Sample Characteristics } & Frequency & Percent \\
\hline Gender & 511 & 35.10 \\
Male & 945 & 64.90 \\
Female & & \\
Faculty & 585 & 40.20 \\
$\quad$ Faculty of Management and Tourism & 21 & 1.40 \\
Faculty of Logistics & 2 & 0.10 \\
Faculty of Informatics & 141 & 9.70 \\
International College & 307 & 21.10 \\
Faculty of Fine Arts & 201 & 13.80 \\
Faculty of Science and Social Science & 192 & 13.20 \\
Faculty of Science and Humanity & 7 & 0.50 \\
Faculty of Agriculture Technology & & \\
Job Status & 1,130 & 77.60 \\
Working & 74 & 5.00 \\
Studying in Graduated School & 27 & 2.00 \\
Working and Studying in Graduated & & \\
School & 226 & 15.40 \\
Looking for Job & & \\
Cooperative Education Program Attention & 851 & 58.40 \\
Yes & 606 & 41.60 \\
No & 1,457 & 100.00 \\
\hline
\end{tabular}

\section{FINDINGS}

Most new graduates who participate in the data collection have the started income at 15,001-20,000 Bath (54.18\%) and period to get the job below 3 months (54.60\%). For data analysis, the author analyzes the data followed the research objectives and divided the results into five tables that show as follow.

\section{A. The Employability of the New Graduates}

Regarding the average of employability classified by participating in the cooperative education program, it was found that totally employability of cooperative students and non-cooperative students were not significantly different. However, when compared to each aspect, it was found that leadership and problem-solving skills of cooperative students and non-cooperative students were significantly different at 0.05 as shown in Table III.

TABLE III: THE EMPLOYABILITY OF THE NEW GRADUATES

\begin{tabular}{|c|c|c|c|c|c|c|}
\hline \multirow{3}{*}{ Employability } & \multicolumn{4}{|c|}{$\begin{array}{c}\text { Cooperative Education Program } \\
\text { Participation } \\
\end{array}$} & \multirow{3}{*}{$t$} & \multirow{3}{*}{$p$} \\
\hline & \multicolumn{2}{|c|}{$\begin{array}{l}\text { Cooperative } \\
\text { students }\end{array}$} & \multicolumn{2}{|c|}{$\begin{array}{c}\text { Non- } \\
\text { Cooperative } \\
\text { students } \\
\end{array}$} & & \\
\hline & $\bar{x}$ & $\mathrm{SD}$ & $\bar{x}$ & SD & & \\
\hline $\begin{array}{l}\text { Management and } \\
\text { Commercial Skill }\end{array}$ & 3.95 & 0.68 & 3.93 & 0.67 & 0.35 & 0.72 \\
\hline $\begin{array}{l}\text { Communication } \\
\text { Skill }\end{array}$ & 4.01 & 0.70 & 4.05 & 0.67 & 1.02 & 0.30 \\
\hline Leadership & 4.20 & 0.77 & 3.80 & 0.82 & 2.36 & $0.03 *$ \\
\hline $\begin{array}{l}\text { Interrelationship } \\
\text { Skill }\end{array}$ & 4.20 & 0.73 & 4.23 & 0.69 & 0.73 & 0.46 \\
\hline $\begin{array}{l}\text { Data Management } \\
\text { and Information } \\
\text { Technology Skill }\end{array}$ & 3.97 & 0.65 & 3.98 & 0.65 & 0.07 & 0.94 \\
\hline Teamwork & 4.16 & 0.71 & 4.14 & 0.70 & 0.43 & 0.66 \\
\hline $\begin{array}{l}\text { Problem Solving } \\
\text { Skill }\end{array}$ & 4.10 & 0.68 & 3.86 & 0.65 & 2.10 & $0.03 *$ \\
\hline Total & 4.03 & 0.49 & 4.04 & 0.50 & 0.56 & 0.72 \\
\hline
\end{tabular}

\section{B. The Career Advancement of New Graduates}

When analyzing the average of career advancement classified by participating in the Cooperative Education Program, the result revealed that the total career advancement and each aspect of career advancement of cooperative students and non-cooperative students were not significantly different as shown in Table IV.

TABLE IV: THE CAREER ADVANCEMENT OF NEW GRADUATES

\begin{tabular}{|c|c|c|c|c|c|c|}
\hline \multirow{3}{*}{$\begin{array}{c}\text { Career } \\
\text { Advancement }\end{array}$} & \multicolumn{4}{|c|}{$\begin{array}{c}\text { Cooperative Education Program } \\
\text { Participation } \\
\end{array}$} & \multirow{3}{*}{$t$} & \multirow{3}{*}{$p$} \\
\hline & \multicolumn{2}{|c|}{$\begin{array}{l}\text { Cooperative } \\
\text { students }\end{array}$} & \multicolumn{2}{|c|}{$\begin{array}{c}\text { Non- } \\
\text { Cooperative } \\
\text { students } \\
\end{array}$} & & \\
\hline & $\bar{x}$ & SD & $\bar{x}$ & $\mathrm{SD}$ & & \\
\hline $\begin{array}{l}\text { Challenged } \\
\text { Work } \\
\text { Assignment }\end{array}$ & 4.10 & 0.66 & 4.08 & 0.70 & 0.71 & 0.47 \\
\hline $\begin{array}{l}\text { Training and } \\
\text { Development }\end{array}$ & 4.04 & 0.74 & 4.07 & 0.76 & 0.70 & 0.48 \\
\hline $\begin{array}{l}\text { Trust and } \\
\text { Empowerment }\end{array}$ & 4.12 & 0.72 & 4.10 & 0.72 & 0.38 & 0.70 \\
\hline $\begin{array}{l}\text { Autonomous } \\
\text { Decision } \\
\text { Making }\end{array}$ & 4.13 & 0.72 & 4.14 & 0.72 & 0.16 & 0.86 \\
\hline $\begin{array}{l}\text { Chance to } \\
\text { Express the } \\
\text { New Idea }\end{array}$ & 4.10 & 0.72 & 4.09 & 0.73 & 0.19 & 0.84 \\
\hline Total & 4.10 & 0.59 & 4.09 & 0.62 & 0.07 & 0.94 \\
\hline
\end{tabular}

\section{The Initial Job and Cooperative Education Program Participation}

Considering the relationship between cooperative education program participation and the initial job, it was found that cooperative education program participation was related to the initial job at statistical significance 0.05 as shown in Table V.

TABLE V: INITIAL JOB AND COOPERATIVE EDUCATION PROGRAM PARTICIPATION

\begin{tabular}{|c|c|c|c|c|c|}
\hline \multirow{3}{*}{ Initial Job } & \multicolumn{4}{|c|}{ Cooperative Education Program Participation } & \\
\hline & \multicolumn{2}{|c|}{ Cooperative students } & \multicolumn{2}{|c|}{$\begin{array}{c}\text { Non- Cooperative } \\
\text { students }\end{array}$} & \\
\hline & Frequency & $\%$ & Frequency & $\%$ & \\
\hline $\begin{array}{l}\text { The job } \\
\text { match the } \\
\text { field of } \\
\text { study }\end{array}$ & 370 & 48.56 & 257 & 47.41 & \\
\hline $\begin{array}{l}\text { The job } \\
\text { does not } \\
\text { match the } \\
\text { field of } \\
\text { study }\end{array}$ & 188 & 24.67 & 195 & 35.97 & $p=0.00^{*}$ \\
\hline $\begin{array}{l}\text { The Job } \\
\text { relates to } \\
\text { the field } \\
\text { of work }\end{array}$ & 204 & 26.77 & 90 & 18.62 & \\
\hline Total & 762 & 100.00 & 542 & 100.00 & \\
\hline
\end{tabular}

\section{The Started Income and Cooperative Education Program Participation}

For the relationship between cooperative education program participation and the started income of new graduates, the result showed the cooperative education program participation statistical significance related to started income at 0.05 as shown in Table VI. 
TABLE VI: STARTED INCOME AND COOPERATIVE EDUCATION PROGRAM PARTICIPATION

\begin{tabular}{lccccc}
\hline \hline \multirow{2}{*}{$\begin{array}{c}\text { Started } \\
\text { Income }\end{array}$} & \multicolumn{2}{c}{ Cooperative Education Program Participation } \\
\cline { 2 - 4 } & Cooperative students & \multicolumn{2}{c}{$\begin{array}{c}\text { Non- Cooperative } \\
\text { students }\end{array}$} & \\
\cline { 2 - 5 } & \multicolumn{4}{c}{$\%$} & \multicolumn{4}{c}{ Frequency } & $\%$ & \\
\cline { 2 - 5 } & Frequency & $\%$ & 146 & 41.95 & $0.00^{*}$ \\
$15,000-$ & 146 & 27.80 & 161 & 46.26 & \\
20,000 & 312 & 59.42 & & & \\
$20,0001-$ & 37 & 7.04 & 26 & 7.47 & \\
25,000 & & & & & \\
$25,001-$ & 30 & 5.74 & 15 & 4.32 & \\
30,000 & & & & & \\
\hline Total & 525 & 100.00 & 348 & 100.00 & \\
\hline \hline
\end{tabular}

\section{E. The Period to Getting New Job and Cooperative Education Program Participation}

Moreover, the result of the relationship between cooperative education program participation and the period to get a new job, the result showed the statistical significant relationship between two variables at 0.05 as shown in Table VII.

TABLE VII: PERIOD TO GETTING NEW JOB AND COOPERATIVE EDUCATION PROGRAM PARTICIPATION

\begin{tabular}{|c|c|c|c|c|c|}
\hline \multirow{3}{*}{$\begin{array}{l}\text { Period to } \\
\text { Getting } \\
\text { New Job }\end{array}$} & \multicolumn{4}{|c|}{ Cooperative Education Program Participation } & \\
\hline & \multicolumn{2}{|c|}{ Cooperative students } & \multicolumn{2}{|c|}{$\begin{array}{c}\text { Non- Cooperative } \\
\text { students }\end{array}$} & \multirow{9}{*}{$p=0.00 *$} \\
\hline & Frequency & $\%$ & Frequency & $\%$ & \\
\hline$<3$ Month & 297 & 48.76 & 266 & 63.03 & \\
\hline 3-6 Month & 127 & 20.85 & 68 & 16.11 & \\
\hline 6-9 Month & 38 & 6.23 & 27 & 6.39 & \\
\hline $9-12$ & 92 & 15.10 & 41 & 9.71 & \\
\hline \multicolumn{5}{|l|}{ Month } & \\
\hline$>1$ year & 55 & 9.06 & 20 & 4.76 & \\
\hline Total & 609 & 100.00 & 422 & 100.00 & \\
\hline
\end{tabular}

\section{DISCUSSION}

The results of the study show that the cooperative students and non-cooperative students had the difference employability in term of problem-solving skills and leadership according to the cooperative student has the opportunity to practice the skills and faced the real work life. Thus, when the cooperative student graduated and work in the organization, they could apply the theory in the work process and adjust their work style that suit the organizational culture. As Gyn, Cutt, Loken, and Ricks [23] which compared the desirable characteristics of a cooperative student and non-cooperative student who graduated from the engineering, science, and liberal arts program, University of Victoria. The study found that the desirable characteristics of the cooperative student and non-cooperative student were different in terms of problem-solving and social roles. Likewise, Murphy, MacGillivary, Reid and Young [24] studied the cognitive style of a cooperative student and non-cooperative student in business administration program. The results showed that the test scores between the cooperative students and the non-cooperative students were different, and the cooperative students have more cognitive style than the non-cooperative students.

For the results of the relationship between the initial job, started income and the period to get the job, the finding found that the participation in cooperative education program correlated with the three variables. According to the relationship between the initial job and the participation in cooperative education program, this may imply the cooperative student would clearly about their career path. As the study of Weston [25], the cooperative students can choose a career path faster than non-cooperative students. Further, Gardner and Motschenbacher [25] compared the expectations of work, job level and initial income between a cooperative student and a non-cooperative student who graduated in engineering, University of Midwest, the result report 80 percent of respondents worked as the engineer and 58 percent of respondents worked start working at the entry level.

The started income related to the participation in the cooperative education program because the employer believes that the cooperative education experience is working experience. The graduates who have joined the cooperative education program had more experience than graduates who have never worked before. Most companies pay salaries based on the length of their experience. In the research of Gardner and Motschenbacher [26], showed cooperative students and non-cooperative students in the Midwestern University received difference income and the cooperative student received the higher average salary. The students who joined the cooperative education program more than two times received a salary more than the student who joined the cooperative education program two times and the non-cooperative student, including [1] noted the students in the cooperative education program will receive higher salaries than non-cooperative students.

Consider the relationship between the periods to get the job and the participation in the cooperative education program, the students who participate in cooperative education program would be practice the job interview skill, application writing skill, and searching job vacancy skill while they applied for the job in the cooperative education program. These skills lead to the short period to get the job [1], as well as in the report of Jancaukas and Goldston [27], identified cooperative student received the higher income, higher job satisfaction and got the job in short period.

\section{CONCLUSION AND SUGGESTION}

The comparison of employability and career advancement in cooperative students and non-cooperative students would be the empirical evidence that can confirm the student benefit from the cooperative education program. From research findings, the cooperative students and non-cooperative students had the difference employability in term of problem-solving skills and leadership because the student who attends the program has a great chance to contact the employer and work in the organization as the temporary worker in the interest area or in the area of study. The practical experience would socialize the cognitive and thinking process of the students. Thus, the cooperative students have more confidence and can identify their career path or career goal faster than the non-cooperative student. Further, the relationship among the cooperative education program attendance, initiated job, stated income, and period to get a job, can enable the academic staffs know the impact 
of the cooperative education.

These results would be lead to the intensive implication of the cooperative education in Thailand and in the other areas, even if the government does not support the financial funding or resource. The academic staffs have to concern the beneficial for the student, especially in the experience and career development. However, the success of new graduates depends on various factors, such lecturers, resources and facilities at the institute, including the student who is the key person in the learning process. According to this study aimed to identify the impact of cooperative education from the student side, thus further research should study the employer perspective about the cooperative education program advantage.

\section{REFERENCES}

[1] M. Weisz and S. Smith, "Critical changes for successful cooperative education," HERDSA, pp. 605-615, 2005.

[2] M. Cullen, "Environmental science cooperative education: Benefits for the students, the host organization, and the study program," Asia-Pacific Journal of Cooperative Education, vol. 6, no. 2, pp. 1-6, 2005.

[3] J. Wilson and E. Lyons, Work-Study College Program: Appraisal and Report of the Study of Cooperative Education, New York: Harper and Brothers, 1961.

[4] H. N. Heinemann, J. W. Wilson, B. R. Heller, and M. Craft, "Cooperative education in the United States of America: a historical perspective," Journal of Cooperative Education, vol. 19, no. 1, pp. 1-14, 1982.

[5] F. Ricks, G. Gyn, G. Branton, J. Cut, M. Loken, and T. Ney, "Theory and research in cooperative education: practice implication," Journal of Cooperative Education, vol. 27, no. 1, pp. 7-20, 1990.

[6] T. N. Garavan and C. Murphy, "The co-operative education process and organizational socialization: A qualitative study of student perceptions of its effectiveness," Education and Training, vol. 43, no. 6 , pp. 281-302, 2001.

[7] J.P. Robinson, "What are employability skills?" The Workplace, vol. 1 , no. 3, pp. 1-3, 2003.

[8] S. Ju, D. Zhang, and J. Pacha, "Employability skills valued by employers as important for entry-level employees with and without disabilities," Career Development for Exceptional Individuals, vol. 35, pp. 29-38, 2012.

[9] R. Heimler, S. Rosenberg, and E. Morate, "Predicting career advancement with structural equation modelling," Education and Training, vol. 54, no. 23, pp. 85-94, 2012.

[10] N. Warraich and K. Ameen, "Employability skill of LIS graduates in Pakistan: needs and expectations," Library Management, vol. 32, no. 3, pp. 209-224, 2011.

[11] N. Wellman, "The employability attributes required of new marketing graduates," Marketing Intelligence and Planning, vol. 28, no. 7, pp. 908-930, 2010

[12] H. M. Yusof, R. Mustapha, S. A. Mohamud, and S. Bunian, "Measurement model of employability skills using confirmatory factor analysis," Procedia Social and Behavioral Science, pp. 348-356, vol. 56, 2012.

[13] M. Rasul, R. Rauf, A. Manzor, M. Yasin, and Z. Mahamod, "Graduate employability for manufacturing industry," Procedia Social and Behavioral Science, pp. 242-250, vol. 102, 2013.

[14] M. Ang, "Graduate employability awareness: A gendered perspective," Procedia Social and Behavioral Science, pp. 192-198, vol. 211, 2015.

[15] L. Golloway, A. Mark, and S. Chillas, "The use of internships to foster employability, enterprise and entrepreneurship in the IT sector,"
Journal of Small Business and Enterprise Development, vol. 21, no.4, pp. 653-667, 2014.

[16] A. Ramli, R. Nawawi, and M. Chun, "Emploees' perspective of employability skills needed in today's workforce among physiotherapy graduates," Procedia Social and Behavioral Science, pp. 455-463, vol. 7, 2010.

[17] M. Husin, S. Mokhlar, A. Ahmad, and R. Mustapha, "Importance of employability skills from employers' perspective," Procedia Social and Behavioral Science, pp. 430-438, vol. 7, 2010.

[18] R. Paguio and B. Jacklong, "Teamwork from accounting graduates: What do employers really expect?" Accounting Research Journal, vol. 29, no. 3, pp. 348-366, 2016.

[19] W. Mondy and J. J. Mortocchio, Human Resource Management, 14th ed, England: Person education, 2016.

[20] J. Allen and E. D. Weert, "What do educational mismatches tell us about skill mismatch? A cross-country analysis," European Journal of Education, vol. 42, no. 1, pp. 59-73, 2007.

[21] R. S. Kaplan, "Reaching your potential," Harvard Business Review, July, pp.45-49, 2008.

[22] J. Robst, "Education and job match: the relatedness of college major and work," Economics of Education Review, vol. 26, no. 4, pp. 397-407, 2007.

[23] G. Gyn, J. Cutt, M. Loken, and F. Ricks, "Investigating the educational benefits of cooperative education: A longitudinal study," Journal of Cooperative Education, vol. 32, no. 2, pp. 70-85, 1997.

[24] H. J. Murphy, A. C. MacGillivary, J. G. Reid, and J. D. Young, "Cognitive style differences between cooperative and non-cooperative education undergraduates: Some preliminary findings," Journal of Cooperative Education, vol. 34, no. 1, pp. 54-6, 2000.

[25] W. D. Weston, "Career identity and its relationship to participation in a cooperative education program," Journal of Cooperative Education, vol. 23, no. 1, pp. 25-36, 1986.

[26] P. D. Gardner and G. Motschenbacher, "Early work outcomes of co-op and non co-op engineers: a comparison of expectations, job level and salary," Journal of Cooperative Education, vol. 33, no. 1, pp. 6-24, 1997.

[27] R. Edwards, E. Jancaukas, and J. Goldston, "Does co-op reality make a difference? Career development opportunities of co-op and non co-op engineering graduated," Conference Proceeding of 11th World Conference on Co-operative Education, 1999.

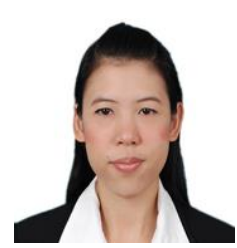

Wannapa Lukitinan was born in Chonburi province, Thailand, on October 24, 1983. She got the Ph.D. in technopreneurship and innovation management at graduate school, Chulalongkorn University, Thailand, in 2012. The major fields of her study are labor employment, human resource management, innovation-oriented human resource management. She has worked as the lecturer at Faculty of Management and Tourism, Burapha University, Thailand since 2013. At present, she holds the Assistant Professor in human resource management at the university. The previous publication include; 1) Organizational climate and individual innovation, in The Advance in Management and Applied Economics Journal 2) Employability and job Mobility: the critical skill for new graduates in ASEAN, in The Global Journal of Business Research, and 3) The relationship between structural empowerment and job satisfaction: a case study of a Thai automobile company, in The World Review of Business Research.

Asst. Prof. Dr. Wannapa Luekitinan has got the best paper award in 2012 Hawaii Global Conference on Business and Finance at Hawaii, USA. She is not only to research in employment and lecturer in human resource management program but also work with the private sector in the Eastern industrial estate of Thailand, such as the eastern personal management association, to develop the bachelor degree curriculum of business administration. 